\title{
Optimization of CFTR-mRNA transfection in human nasal epithelial cells
}

\author{
Elena Fernández Fernández, Nadine Bangel-Ruland, Katja Tomczak and Wolf-Michael Weber
}

\begin{abstract}
Background: Cystic fibrosis (CF) is the most common life-threatening inherited disease in the Caucasian population. It is caused by genetic defects in the cystic fibrosis transmembrane conductance regulator gene (CFTR), a CAMP regulated chloride-bicarbonate channel mainly located in the apical membrane of polarized epithelial cells. CFTR is proposed to regulate other proteins, including the epithelial sodium channel (ENaC). Recently, we successfully restored chloride current in CFTR deficient human airway epithelial cells using wtCFTR-mRNA transfection compared to non-CF cells showing similar values. The present study aimed to optimize the wtCFTR-mRNA transfection procedures in primary cultured human nasal epithelial (HNE) cells.
\end{abstract}

Methods: Dose and time dependence experiments were performed. In addition, we investigated the possible impact of the wtCFTR-mRNA transfection on ENaC function in transepithelial measurements. We reduced the wtCFTR-mRNA dose stepwise and determined the minimal concentration of $0.6 \mu \mathrm{g} / \mathrm{cm}^{2}$, which is needed for the most efficient restoration of CFTR function. Furthermore, CFTR expression was evaluated 24, 48 and $72 \mathrm{~h}$ after transfection.

Results: Using the minimal concentration of $0.6 \mu \mathrm{g} / \mathrm{cm}^{2}$ wtCFTR-mRNA we confirmed a positive functional CFTR restoration over a period of $72 \mathrm{~h}$. Biochemical analyses confirmed these findings. Furthermore, we could not find any significant effect on ENaC after the recovery of CFTR by wtCFTR-mRNA transfection.

Conclusions: Our data show that wtCFTR-mRNA transfection is an encouraging alternative "gene" therapy in human primary culture.

Keywords: Cystic fibrosis, mRNA, Transfection, Primary cultured cells

\section{Background}

Cystic fibrosis (CF) is a life-limiting autosomal recessive disorder in the Caucasian population, affecting around 70.000 individuals worldwide. The disease is caused by genetic defects in the cystic fibrosis transmembrane conductance regulator gene (CFTR) that encodes for a cyclic adenosine monophosphate (CAMP) -regulated chloride channel. CFTR is expressed in the plasma membrane of secretory epithelia- such as airways, intestine, pancreas, testis and exocrine glands- as well as in some nonepithelial cells types [1]. At the cell membrane CFTR exhibits its function as a chloride channel and it is proposed to regulate other membrane proteins, including the epithelial sodium channel $(\mathrm{ENaC})$ [2]. CFTR and $\mathrm{ENaC}$ play the most important role in maintaining

\footnotetext{
* Correspondence: wmw@uni-muenster.de

Institute of Animal Physiology, University of Muenster, Schlossplatz 8, D-48143 Münster, Germany
}

homeostasis of airway surface liquid (ASL) by controlling the movement of water through the epithelium, thus regulating the hydration of the epithelial surface in many organs, but predominantly in the airways. It has been demonstrated that $\mathrm{Na}^{+}$absorption is enhanced in CF airways and contributes to the pathogenesis of the disease [3]. However, the interactions between CFTR and ENaC are still not fully understood and the mechanism (s) remain unknown [4]. The defect in CF cells due to the impaired chloride transport and ion transport disturbances evokes abnormally viscous secretions in the airways causing obstructions that lead to bacterial infections [5], inflammation, tissue damage and destruction of the organ. Obstructive lung failure is currently the primary cause of morbidity and is responsible for $80 \%$ of mortality [6].

The discovery of the CFTR gene in 1989 [7] created new possibilities for a curative treatment targeting the basic defect rather than treating the symptoms of the $\mathrm{CF}$ 
disease [8]. Due to the significant improvements, survival has been increased substantially [9] over the last few decades in the treatment of CF. Gene therapy has been pointed out as the forefront to overcome this difficult challenge [10]. The potential of mRNA for therapeutic protein expression in vivo has been investigated as an alternative to DNA-based gene therapy. The preclinical exploration in the 1990s of the synthetic mRNA was initiated for diverse applications, including protein substitution for cancer and infectious diseases [11, 12]. Nevertheless, cancer immunotherapy is the only field in which clinical testing of mRNA is at an advanced stage [13].

Recently, we established a new strategy to deliver CFTRmRNA directly to epithelial cells [14]. We showed a proofof-concept for mRNA-based functional restoration of impaired CFTR functions in the cell culture, either using human bronchial CF cells (CFBE41o-) that stably express the most common mutation F508del-CFTR or primary cultured human epithelial (HNE) cells [14]. We showed that after mRNA transfection the CFBE41o- cells functionally act very similar after cAMP stimulation compared to healthy bronchial epithelia cells (16HBE41o-). Furthermore, the amount of functional CFTR molecules in the CF cells after mRNA transfection is even larger than in non-CF control cells [14]. Using the CF cell line or HNE cells wtCFTRmRNA transfection procedures were performed using a dose of $2.4 \mu \mathrm{g} / \mathrm{cm}^{2}$ and $24 \mathrm{~h}$ after transfection the analyses were carried out.

In order to give more physiological relevance we only used primary HNE cells in our study. In vitro cell culture models of human nasal epithelium based on primary culture technologies are known to be extremely useful for permeability and transport studies in healthy and disease tissues [15]. Furthermore, cultured nasal cells are reliable models since they are known to express important biological features such as tight junctions, mucin secretion, cilia, transporters comparable to those found in vivo systems [16]. Thus, the use of primary human nasal cell culture systems could accurately represent an alternative to in vivo situations. In addition, nasal epithelial cells could be used as a substitute for bronchial epithelial cells as they show identical morphologies with similar expression of receptors and responses to cytokine stimulation [17].

The major purpose of the present study was to optimize the dose of wtCFTR-mRNA as well as the determination of the time for a suitable CFTR expression in primary HNE cells. We determined the optimal mRNA concentration reducing the transfection dose needed for the successful recovery of the CFTR function. Furthermore, we performed time dependent studies with the minimal wtCFTR-mRNA concentration in order to evaluate the duration of the CFTR protein expression after mRNA transfection. In addition, after the efficient restoration of CFTR function, we investigated the possible impact of the CFTR-mRNA transfection on ENaC. Since primary cultured nasal epithelial cells show only a low chloride secretion but a positive amiloride-sensitive $\mathrm{ENaC}$ current, it is an excellent cell model for the investigation of CFTR and ENaC interactions [4]. We concluded that mRNA delivery, termed "transcript therapy" [18] is an encouraging alternative in human primary culture offering a promising opportunity for the study of $\mathrm{CF}$ and the potentially clinical therapies in patients suffering from this incurable disease.

\section{Methods \\ mRNA synthesis}

For in vitro transcription (IVT) we used the pSTIA120/hCFTR cDNA (construct provided by C. Rudolph, Maximilian University of Munich, Munich, Germany). The mRNA synthesis was performed as described previously [14]. Briefly, the linearized plasmids were extracted with phenol/chloroform and precipitated with ethanol. The IVT reaction was carried out using the mMessage mMachine Kit (Ambion, Foster City, USA). The reaction was purified using the RNeasy plus Mini Kit (Quiagen, Hilden, Germany) and ethanol/ammonium acetate precipitation was done to achieve good quality. The concentration of mRNA was determined by absorbance measurement at $260 \mathrm{~nm}$ using a microvolume spectrophotometer (Nanodrop, Thermo Scientific, Wilmington, DE, USA). The integrity and size distribution of mRNA was determined by agarose gel electrophoresis and ethidium bromide staining. The generated mRNA was stored at $-80^{\circ} \mathrm{C}$ in nuclease-free water.

\section{Cell culture}

Primary cell culture of HNE cells was performed as described previously [19]. Briefly, cells were isolated by enzymatic digestion for 24-72 $\mathrm{h}$ and afterwards seeded on collagen coated $(0.15 \mathrm{mg} / \mathrm{ml}$ collagen type I; Biochrom AG, Berlin, Germany) Transwell permeable filters (diameter $6.5 \mathrm{~mm}$, Costar 3470; Corning Inc., Lowell, MA, USA) for transepithelial measurements, on coated cell culture dishes (diameter $35 \mathrm{~mm}$ ) for biochemistry analyses or on coated glass coverslips (diameter $12 \mathrm{~mm}$ ) for optical fluorescence assays. The cells were cultured with serum-free F-12 Nutrient Mixture (Ham) (Invitrogen/ Gibco, Kahlsruhe, Germany) supplemented with insulin (2 $\mathrm{g} / \mathrm{ml})$ (Invitrogen, Gibco), epidermal growth factor (12 ng/ml) (Sigma, Deisenhofen, Germany), endothelial cell growth supplement $(7.5 \mathrm{~g} / \mathrm{ml})$ (Becton Dickinson $\mathrm{GmbH}$, Heidelberg, Germany), triiodo-thyronine (3 $\mathrm{nM})$ (Sigma), hydrocortisone (100 nM) (Sigma), gentamycin (10 g/ml) (Biochrom AG), penicillin/streptomycin (100 U/ $\mathrm{ml}$ ) (Invitrogen/Gibco), L-glutamine (2 $\mathrm{mM})$ (Invitrogen/ Gibco) and transferrin $(4 \mathrm{~g} / \mathrm{ml})$ (Invitrogen/Gibco). Fibroblast contamination is reduced by the use of serum-free media and cluster formation is avoided by filtering through 
special cell strainers. In addition, epithelial purity of the HNE cells was confirmed using specific antibodies against vimentin and keratin. Cells were incubated in $95 \%$ air and $5 \% \mathrm{CO}_{2}$ at $37{ }^{\circ} \mathrm{C}$. Cells were seeded on the membrane and a confluent monolayer was obtained after 7 to 9 days.

\section{Transfection efficiency and fluorescence optical analyses} The in vitro transfection efficiency of Lipofectamine $e^{T M}$ 2000 (Invitrogen) was evaluated in HNE cells using the pEGFP-C1 plasmid (Clontech/Takara Bio Europe, SaintGermain-en-Laye, France). Co-transfection of pEGFP-C1 and GFP- siRNA and $\mathrm{H}_{2} \mathrm{O}$ transfections were used as controls. Cells were seeded on coverslips 2 days before transfection and were cultivated in HNE culture medium. The day of transfection confluence of the cells was greater than $80 \%$. Three hours before transfection, cells were cultivated in HNE culture medium without antibiotics. Cells were transfected with $1 \mu \mathrm{g}$ of pEGFP-C1 or co-transfected with $2.5 \mathrm{pmol} / \mathrm{cm}^{2}$ GFP-siRNA (negative control) or a respective amount of nuclease free water. After $48 \mathrm{~h}$ of incubation, cells were fixed with $0.05 \%$ glutaraldehyde and autofluorescence was quenched with $0.1 \%$ sodium borohydride. Analysis of the fluorescence intensities was determined using a fluorescence microscope (LSM 510 META; Carl Zeiss, Oberkochen, Germany). The images were recorded using the AxioCamMRm and the LSM 5104.2 SP1 software (Carl Zeiss). The exposure time was adjusted manually for comparison of total fluorescence intensities. For compensation images, confluent regions of the cell layer were used for the analysis.

\section{wtCFTR-mRNA transfection procedure}

For transfection experiments HNE cells were seeded on collagen coated Transwell permeable filters or on coated cell culture dishes and cultivated for 7 to 9 days. The cell culture medium was replaced every 2 days. Twenty-four hours before transfection, the medium was removed, and fresh HNE culture medium without antibiotics was added. In all experiments, Lipofectamine ${ }^{T M} 2000$ was used as transfection reagent. The experiments were performed in accordance to the manufacturer's instructions using Opti-MEM as transfection medium. Transfection complexes were replaced after $4-6 \mathrm{~h}$ with normal HNE culture medium.

\section{Dose dependence studies}

Cells were transfected with different concentrations of wtCFTR-mRNA $\left(2.4 \mu \mathrm{g} / \mathrm{cm}^{2}, 1.2 \mu \mathrm{g} / \mathrm{cm}^{2}, 0.6 \mu \mathrm{g} / \mathrm{cm}^{2}\right.$, $0.3 \mu \mathrm{g} / \mathrm{cm}^{2}$ ) and experiments were performed $24 \mathrm{~h}$ after transfection.

\section{Time dependence studies}

HNE cells were transfected with the optimal concentration of $0.6 \mu \mathrm{g} / \mathrm{cm}^{2}$ and analyses were carried out 24,48 and $72 \mathrm{~h}$ after transfection.

\section{Transepithelial measurements}

Modified Ussing chambers designed by Prof. Willy Van Driessche (KU Leuven, Belgium) were used to perform the transepithelial measurements. Ag/Ag electrodes were connected to Ringer solution $(130 \mathrm{mM} \mathrm{NaCl}, 5 \mathrm{mM}$ $\mathrm{KCl}, 1 \mathrm{mM} \mathrm{CaCl} 2,2 \mathrm{mM} \mathrm{MgCl} 2,5 \mathrm{mM}$ glucose and $10 \mathrm{mM}$ HEPES, $\mathrm{pH} 7.3,37{ }^{\circ} \mathrm{C}$ ) and the transepithelial potential $\left(\mathrm{V}_{t}\right)$ was clamped to zero. The two compartments of the Ussing chamber, apical and basolateral, were continuously perfused with cell culture Ringer solution. The short-circuit current $\left(\mathrm{I}_{\mathrm{sc}}\right)$, which reflects the transported net charges over the epithelium was constantly monitored (ImpsDsp 1.4; KU Leuven). The parameter was normalized to $1 \mathrm{~cm}^{2}$. After stabilization of the parameters, a cAMP (8-[4-chlorophenylthio (CTP)]-cAMP) (100 mM; Biolog, Bremen, Germany)/ IBMX (1 mM; ApplieChem $\mathrm{GmbH}$, Darmstadt, Germany) cocktail was applied on the basolateral side to activate CFTR. Subsequently, CFTR was inhibited using the specific blocker CFTRinh172 (20 $\mu \mathrm{M}$; Tocris Bioscience, Bristol, UK). In addition, the $\mathrm{Na}^{+}$absorption through ENaC was assessed as shortcircuit current in the presence and absence of amiloride $(100 \mu \mathrm{M})$. Therefore, the effect of the wtCFTR-mRNA transfection on the amiloride current via $\mathrm{ENaC}$ was investigated. If not otherwise stated, all chemicals were obtained from Roth (Karlsruhe, Germany).

\section{Protein biochemistry}

For Western Blot experiments HNE cells were detached from culture dishes using $400 \mu \mathrm{l}$ of lysis buffer $(1 \mathrm{mM}$ Tris, $15 \mathrm{mM} \mathrm{NaCl}, 0.2 \mathrm{mM}$ EDTA, 2 \% Triton X-100) and $1 \%$ protease inhibitor cocktail (Sigma). The extracts were homogenized with a sonifier ultrasonic cell disrupter (Branson, Danbury, CT, USA) and placed on ice for $10 \mathrm{~min}$. The lysate was centrifuged at $4000 \mathrm{~g}$ for $30 \mathrm{~min}$ at $4{ }^{\circ} \mathrm{C}$ to pellet the cell debris and the supernatant was used. The concentration of the proteins was determined using the BCA test (Pierce, Rockford, IL, USA). $40 \mu \mathrm{g}$ total protein were separated via SDS-PAGE (7.5 \% acrylamide) and subsequently transferred to a polyvinylidene fluoride PVDF membrane using a semidry blotting system. Non-specific bindings sites were blocked for $2 \mathrm{~h}$ at RT with $5 \%$ non-fat dry milk in Trisbuffered saline/Tween (TBS-T: $10 \mathrm{nM}$ Tris $\mathrm{HCl}, \mathrm{pH}$ 7.4; $140 \mathrm{nM} \mathrm{NaCl} ; 0.05 \%$ Tween 20). CFTR protein was detected using an anti- CFTR antibody (ABR-01129; Dianova, Hamburg, Germany) in a 1: 500 concentration diluted in $5 \%$ non-fat dry milk/TBS-T overnight at $4{ }^{\circ} \mathrm{C}$ continuously shaking. Vimentin and keratin proteins were detected using anti-vimentin and anti-keratin antibody, respectively (Dianova, Hamburg, Germany) in a 1: 500 concentration diluted in $5 \%$ non-fat dry milk/TBS-T overnight at $4{ }^{\circ} \mathrm{C}$ continuously shaking. After $24 \mathrm{~h}$, the membrane was washed in TBS-T three times for $10 \mathrm{~min}$ 
and incubated with the secondary antibody goat antimouse Ig G conjugated with horseradish peroxidase (HRP) (Dianova) diluted 1: 10,000 in $5 \%$ non-fat dry milk/TBS-T for one hour at room temperature continuously shaking. Then, the membrane was washed again three times in TBS-T for $10 \mathrm{~min}$ and once in TBS. The detection was carried out with enhanced chemiluminiscence (ECL). To assure comparable protein amount and expression, antialpha-tubulin (Tubulin, alpha, DLN-09993; Dianova) was used for normalization. Image J, version 1.41 (Wayne Rasband, National Institutes of Health, Bethesda, MD, USA) was used for densitometry evaluation of the CFTR band intensity.

\section{Analysis of fluorescence intensities}

Analysis of total fluorescence intensities was performed using ImageJ, version 1.41. The plug-in for RGB (Red, Green, Blue) measurement analyses the intensity of each channel of an image and displays the average channel intensity $[(R+G+B) / 3]$. The generated value was employed for analysis and was compared with that of other images. The average of non-transfected cells was set to $100 \%$ and the transfected average was normalized to that value to be expressed as a multiple of the non-transfected value.

\section{Statistical analysis}

Data are presented as the arithmetic means $( \pm$ SEM). Sets of data were compared with Student's $t$-test. Differences were considered statistically significant when $p<0.05\left(^{*}\right)$ or $p<0.01\left(^{(*)}\right)$. In all experiments, $\mathrm{n}$ gives the number of replications. All statistical tests were performed using Origin, version 7.0 (Originallab Corporation, Northampton, USA).

\section{Results}

\section{Characterization of primary HNE cells}

The determination of the purity of the HNE culture is a key factor in order to validate further experiments. Vimentin is the main intermediate filament in mesenchymal cells and was used to detect non-epithelial cells. The primary human umbilical vein endothelial cells (HUVEC) served as positive control for vimentin expression [20]. In Western blot experiments (see Fig. 1) a specific band of vimentin was detected in the range of 57-60 kDa solely in the HUVEC sample, while in the other samples, the human bronchial epithelial cell lines (16HBE14o- and CFBE41o-) and primary HNE cells any band was found. Additionally, a specific band for keratin in the range of $45 \mathrm{kDa}$ in all separated samples (HUVEC, 16HBE140-, CFBE41o- and primary HNE cells) was detected. As expected, no vimentin expression in the analyzed cells, except for HUVEC, was observed. Hence, the characterization of the HNE cells as pure epithelial cells was verified.

\section{Transfection efficiency}

The transfection efficiency was determined for the primary cultured HNE cells. It is expressed as the proportion of cells that express the transgene among all cells in the culture dish. In addition, multiple experimental factors (transfection method, health and viability of the cells, degree of confluence, etc.) can influence the transfection procedure [21]. High transfection efficiencies and low toxicity are the primary requirements of an ideal gene delivery vector [22]. In this approach, the green fluorescence protein (GFP) was used as a reporter. In Fig. 2, representative fluorescent images of pEGFP transfected cells are shown. The intensity of the fluorescent signal is used as an indicator of transfection efficiency. The statistical evaluation of the fluorescence intensities is shown in Fig. 2 and demonstrates that cells transfected with pEGFP exhibited considerable elevated fluorescence as compared to controls after $24 \mathrm{~h}$. The total fluorescence intensity in GFP transfected cells was almost $226 \%$ higher as compared to the controls. The different negative controls reflect fluorescence intensities similar to control cells in all experiments. Analyzing this data, high transfection efficiencies for the primary cultured cells using Lipofectamine as transfection reagent were observed.
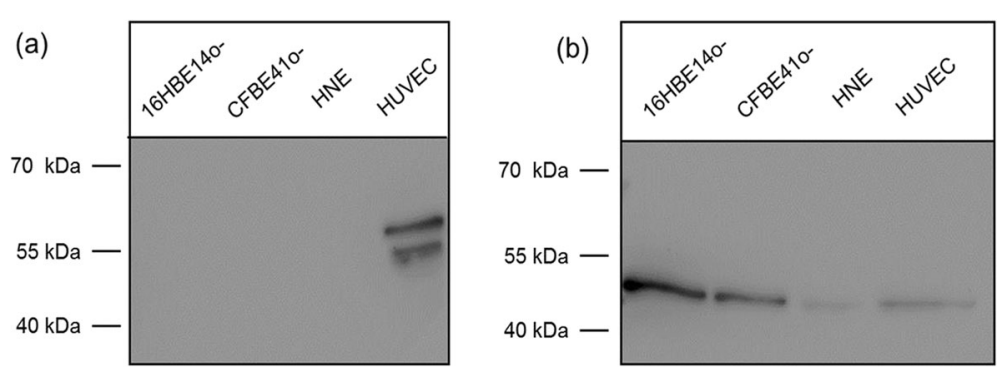

Fig. 1 Representative Western blot. Proteins (40 $\mu \mathrm{g}$ ) from two human bronchial epithelial cell lines (16HBE140- and CFB410-), primary human nasal epithelial (HNE) cells and human umbilical vein endothelial cells (HUVEC) were isolated by using $2 \%$ Triton X-100 and separated on a $10 \%$ SDS-PAGE. To identify the characteristic protein bands of vimentin (a) and keratin (b) we used a mouse monoclonal anti-vimentin and a mouse monoclonal anti-keratin antibody (Dianova), respectively. As secondary antibody we used a goat anti-mouse lgG-HRP conjugated antibody (Dianova). We detected a specific band of vimentin in the range of 57-60 kDa solely in the HUVEC sample and a specific band of keratin in the range of $45 \mathrm{kDa}$ in all separated samples 

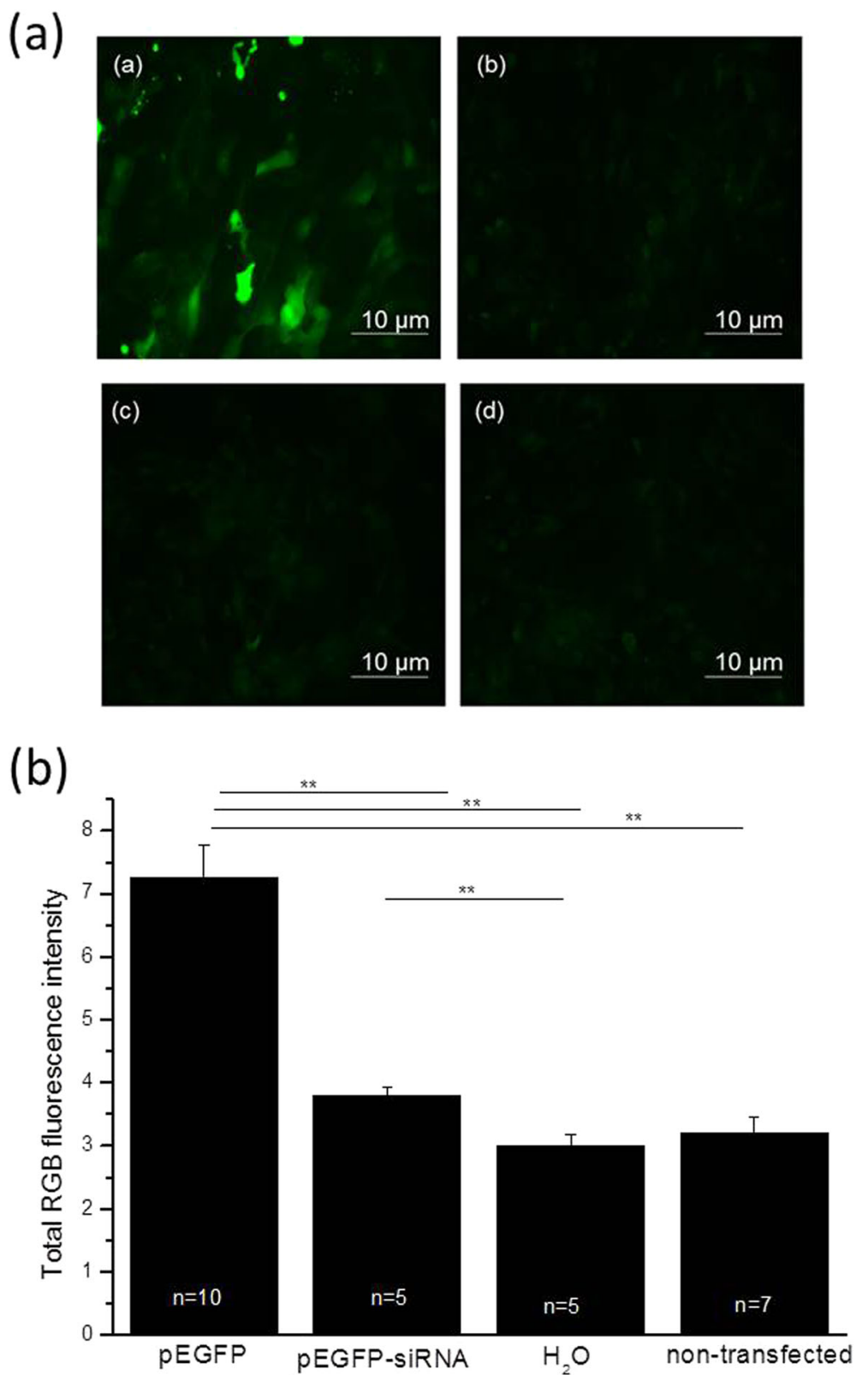

Fig. 2 Transfection efficiency of HNE cells. Cells were analyzed $24 \mathrm{~h}$ after transfection. a Samples transfected with GFP (a) exhibited a markedly increased fluorescence as compared to controls after $24 \mathrm{~h}$ ( $b$ : water transfected, $c$ : nonbinding siRNA, $d$ : non-transfected). $\mathbf{b}$ Statistical evaluation of fluorescence intensities of the primary HNE cells. An increase of approximately $226 \%$ is shown in GFP transfected cells compared to the controls. Measurements of the different negative controls revealed fluorescence intensities comparable to control cells in all experiments $\left({ }^{*} p \leq 0.05 ;{ }^{* *} p \leq 0.01\right)$

\section{Dose response studies}

\section{Electrophysiological measurements}

In initial studies, the transfection of primary cultured HNE cells was performed using an mRNA concentration of $2.4 \mu \mathrm{g} / \mathrm{cm}^{2}$ and $24 \mathrm{~h}$ after transfection transepithelial measurements were carried out. The statistical analysis revealed a successful increase of almost two-fold of the CFTR current in transfected cells compared to controls (non-transfected cells) [14]. Because of these positive results, dosage was stepwise reduced $\left(2.4 \mu \mathrm{g} / \mathrm{cm}^{2}, 1.2 \mu \mathrm{g} /\right.$ $\left.\mathrm{cm}^{2}, 0.6 \mu \mathrm{g} / \mathrm{cm}^{2}, 0.3 \mu \mathrm{g} / \mathrm{cm}^{2}\right)$ in order to find the minimal concentration that is sufficient for the restoration of the functional cAMP dependent CFTR current. Therefore, confluent monolayer of primary cultured HNE cells were used to measure the transepithelial short-circuit current $\left(\mathrm{I}_{\mathrm{sc}}\right)$ in the Ussing chamber. Generally, in HNE cells, the CFTR activation is not markedly increased due to the low expression of the CFTR protein in the nasal tissue $[23,24]$. After the application of the cAMP-cocktail, $\mathrm{I}_{\mathrm{sc}}$ was increased $\left(2.8 \pm 0.5 \mu \mathrm{A} / \mathrm{cm}^{2} ; n=39\right)$ in the control 


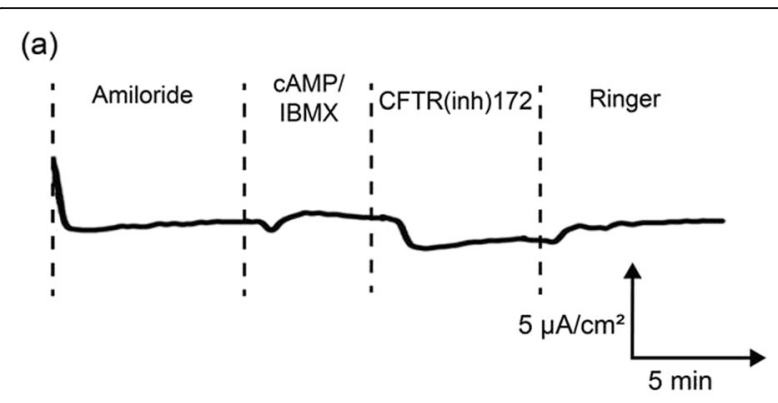

(b)

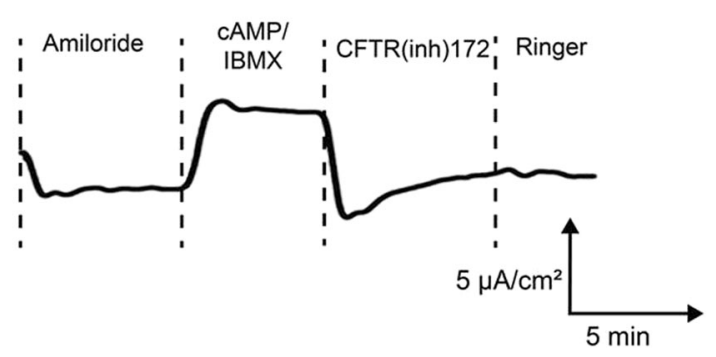

Fig. 3 Time course of a typical transepithelial measurement. Shown is the short circuit current $\left(I_{s c}\right)$ in HNE cells (non-transfected = controls) (a) and wtCFTR-mRNA transfected HNE cells (b) respectively. After the application of the CAMP-cocktail $I_{s c}$ smoothly increased in the control cells as shown in (a). In a second step, the chloride current was inhibited with the specific inhibitor CFTRinh172. When HNE cells were transfected with wtCFTR-mRNA, Isc increased, by the application of CAMP, which could be inhibited by the inhibitor CFTRinh172. The CAMP activation of CFTR is boosted by the transfection demonstrating functional expression of CFTR

cells (Fig. 3a). $24 \mathrm{~h}$ after the transfection with $2.4 \mu \mathrm{g} / \mathrm{cm}^{2}$ wtCFTR-mRNA, a markedly increase $\left(5.2 \pm 0.6 \mu \mathrm{A} / \mathrm{cm}^{2}\right.$; $n=36$ ) of the short-circuit current (Fig. 3b) was observed, demonstrating successful expression of CFTR after wtCFTR-mRNA transfection. Moreover, in a second step, this functional expression of CFTR was also inhibited by the specific CFTR blocker CFTRinh172, resulting in a decrease in the CFTR current. A dose-dependent increase of the CFTR circuit current was observed after decreasing the concentration of wtCFTR-mRNA from 2.4 to $0.6 \mu \mathrm{g} /$ $\mathrm{cm}^{2}$ (Fig. 4). Therefore, when reducing the mRNA amount to $0.6 \mu \mathrm{g} / \mathrm{cm}^{2}$, it was observed that this concentration is the minimal and also the most suitable dose to achieve an increase in the CFTR current $\left(9.3 \pm 2.0 \mu \mathrm{A} / \mathrm{cm}^{2} ; n=19\right)$. Reducing the concentration to $0.3 \mu \mathrm{g} / \mathrm{cm}^{2}$ wtCFTR-mRNA, the $I_{\mathrm{sc}}$ was significantly decreased after the application of the cAMP/IBMX cocktail $\left(2.5 \pm 2.4 \mu \mathrm{A} / \mathrm{cm}^{2} ; n=6\right)$. In control cells, the application of the inhibitor had no effect on the current, while in wtCFTR-mRNA transfected cells with a dose of $0.6 \mu \mathrm{g} / \mathrm{cm}^{2}(n=19)$ a $72.93 \%$ inhibition of the cAMP activated CFTR current was observed. The increased inhibition of CFTR current in HNE cells transfected with $0.6 \mu \mathrm{g} / \mathrm{cm}^{2}$ wtCFTR-mRNA may demonstrate that more CFTR molecules are expressed after mRNA transfection than in control cells (non-transfected). As a concentration of $0.6 \mu \mathrm{g} / \mathrm{cm}^{2}$ wtCFTR-mRNA had the strongest effects on CFTR current, all further experiments were performed with this concentration.

\section{Western blot analyses}

To test whether the transfection of wtCFTR-mRNA increases CFTR protein level, we analysed the expression of CFTR concerning to the mRNA dose in HNE cells and subsequently we carried out semi-quantitative Western blot assays with a specific monoclonal anti-CFTR antibody. This antibody detects a CFTR band in the range of 170 $\mathrm{kDa}$ (Fig. 5). Tubulin was used as a control in the WB experiments for the further normalization analyses. The band of tubulin is detected in the range of $55 \mathrm{kDa}$. The transfections with the different wtCFTR-mRNA doses $\left(2.4 \mu \mathrm{g} / \mathrm{cm}^{2}\right.$, $1.2 \mu \mathrm{g} / \mathrm{cm}^{2} 0.6 \mu \mathrm{g} / \mathrm{cm}^{2}$ ) were performed and $24 \mathrm{~h}$ after Western blot assays were carried out. We found a nearly doubled (1.8-fold) CFTR protein expression when using the minimal dose of $0.6 \mu \mathrm{g} / \mathrm{cm}^{2}$. These results confirm our findings of the electrophysiological analyses and demonstrate that $0.6 \mu \mathrm{g} / \mathrm{cm}^{2}$ wtCFTR-mRNA is the optimal dose for the overexpression of CFTR in primary HNE cells.

\section{Time response studies}

\section{Electrophysiological measurements}

We evaluated if the positive wtCFTR-mRNA transfection effect could sustain the CFTR function over a longer period of time. Therefore, the persistence of the CFTR expression 24, 48 and $72 \mathrm{~h}$ after transfection with the optimal dose of $0.6 \mu \mathrm{g} / \mathrm{cm}^{2} \mathrm{mRNA} \mu \mathrm{g} / \mathrm{cm}^{2}$ was analysed. To investigate this, we carried out transepithelial measurements in modified Ussing chambers. In Fig. 6 the $I_{s c}$ the time dependent decrease is shown. The highest CFTR restoration was achieved $24 \mathrm{~h}\left(9.3 \pm 2.0 \mu \mathrm{A} / \mathrm{cm}^{2} ; n=19\right)$ after CFTR-mRNA transfection. After that point a gradual decrease was observed. Nevertheless, over a period of $72 \mathrm{~h}$ the CFTR mediated current was still confirmed (5.2 \pm $\left.0.6 \mu \mathrm{A} / \mathrm{cm}^{2} ; n=6\right)$ compared to controls $(2.8 \pm 0.5 \mu \mathrm{A} /$ $\left.\mathrm{cm}^{2} ; n=35\right)$. In addition, the inhibition by the specific inhibitor CFTRinh172 is expanded in the wtCFTR-mRNA transfected cells but was not observed in the control cells $24 \mathrm{~h}$ after transfection we measured a $72.93 \%$ inhibition of the cAMP activated CFTR current, which was still observed $72 \mathrm{~h}$ after transfection (27.08\%). These results show that even after $72 \mathrm{~h}$ after wtCFTR-mRNA transfection an increase in CFTR current was observed.

\section{Western blot analyses}

In addition, we performed Western Blot assays using a specific antibody that binds to CFTR. HNE cells were transfected with the optimal dose of $0.6 \mu \mathrm{g} / \mathrm{cm}^{2}$ CFTR-mRNA and 24 and $48 \mathrm{~h}$ experiments were performed. To identify CFTR, we used a monoclonal anti-CFTR antibody that 

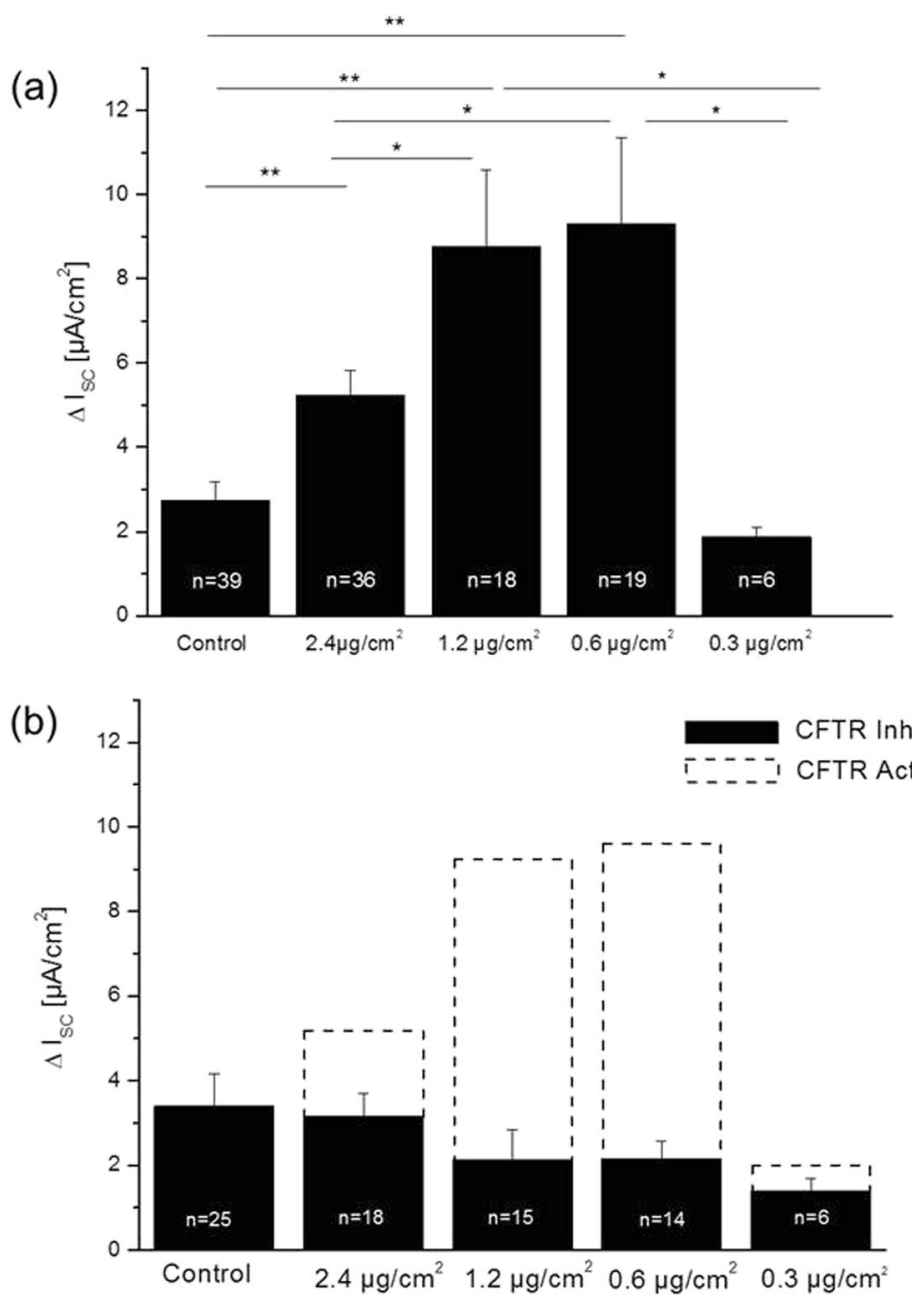

Fig. 4 Statistical evaluation of the wtCFTR-mRNA dose dependency. a Shown are the short-circuit values $\left(I_{s c}\right)$ of CFTR activation by cAMP addition and the inhibition by CFTRinh172 application in HNE cells. The stepwise decrease of the transfection dose $\left(2.4 \mu \mathrm{g} / \mathrm{cm}^{2}, 1.2 \mu \mathrm{g} / \mathrm{cm}^{2}, 0.6 \mu \mathrm{g} / \mathrm{cm}^{2}\right.$ and $0.3 \mu \mathrm{g} / \mathrm{cm}^{2}$ ) produced (FTR activation after the CAMP application. The most efficient CFTR activation was reached using the mRNA dose of $0.6 \mu \mathrm{g} / \mathrm{cm}^{2}\left(9.3 \pm 2.0 \mu \mathrm{A} / \mathrm{cm}^{2} ; n=19\right)$ compared to the controls cells $\left(2.8 \pm 0.5 \mu \mathrm{A} / \mathrm{cm}^{2} ; n=39\right)$. The subsequent reduction to a concentration of $0.3 \mathrm{\mu g} / \mathrm{cm}^{2}$ did not show any proper activation of CFTR. $\mathbf{b}$ The inhibition by the CFTRinh172 is also increased in the wtCFTR-mRNA transfected cells. Although, we could not observe a reduction by the inhibitor in the control cells, we found a $72.93 \%$ inhibition of the CAMP activated CFTR current in the wtCFTR-mRNA transfected cells with a dose of $0.6 \mu \mathrm{g} / \mathrm{cm}^{2}(n=19)$. The higher rate of inhibition in transfected HNE cells with the dose of $0.6 \mathrm{\mu g} / \mathrm{cm}^{2}$ may demonstrate that more CFTR molecules are expressed after mRNA transfection than in control cells (non-transfected) $\left({ }^{*} p<0.05 ;{ }^{* *} p<0.01\right.$ )

detects a CFTR band in the range of $170 \mathrm{kDa}$. In addition, we detected tubulin in the range of $55 \mathrm{kDa}$ for normalization analyses. Figure 7 shows the statistical evaluation of the relative CFTR protein amount. Twenty-four hours after wtCFTR-mRNA transfection 1.5-fold more CFTR protein is expressed. These results confirm our findings of the electrophysiological analysis.

\section{Influence of wtCFTR-mRNA on ENaC}

Cells of HNE were stepwise transfected with different concentrations of wtCFTR-mRNA $\left(2.4 \mu \mathrm{g} / \mathrm{cm}^{2}, 1.2 \mu \mathrm{g} / \mathrm{cm}^{2}\right.$, $\left.0.6 \mu \mathrm{g} / \mathrm{cm}^{2}\right)$ and $24 \mathrm{~h}$ before the experiments in modified Ussing chambers were carried out. Furthermore, time dependence studies 48 and $72 \mathrm{~h}$ using $0.6 \mu \mathrm{g} / \mathrm{cm}^{2}$ wtCFTR-
mRNA were performed. $\mathrm{Na}^{+}$absorption by $\mathrm{ENaC}$ was assessed as short-circuit current in the presence and absence of amiloride $(100 \mu \mathrm{M})$. To determine the overall $\mathrm{Na}^{+}$ absorption of the cells, $\mathrm{Na}^{+}$was removed from the apical Ringer in a second step. Transfection of HNE monolayers with wtCFTR-mRNA resulted in a decreasing trend due to amiloride response, indicating that the expression of $\mathrm{ENaC}$ is reduced by wtCFTR-mRNA transfection: $2.4 \mu \mathrm{g} / \mathrm{cm}^{2}$ (32.85 \% $\pm 3.8 ; n=34), 1.2 \mu \mathrm{g} / \mathrm{cm}^{2}(27.92 \% \pm 5.1 ; n=18)$ and $0.6 \mu \mathrm{g} / \mathrm{cm}^{2}(25.03 \% \pm 5.9 ; n=19)$. Nevertheless, the statistical evaluation (Fig. 8) of the performed measurements revealed no significant differences between the different mRNA doses with regard to the amiloride sensitive current. Therefore, only a decreasing tendency in the 


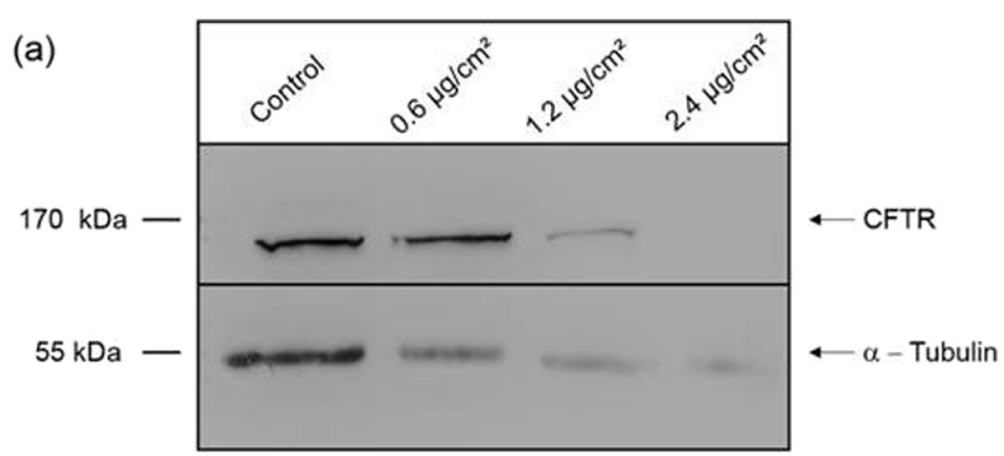

(b)

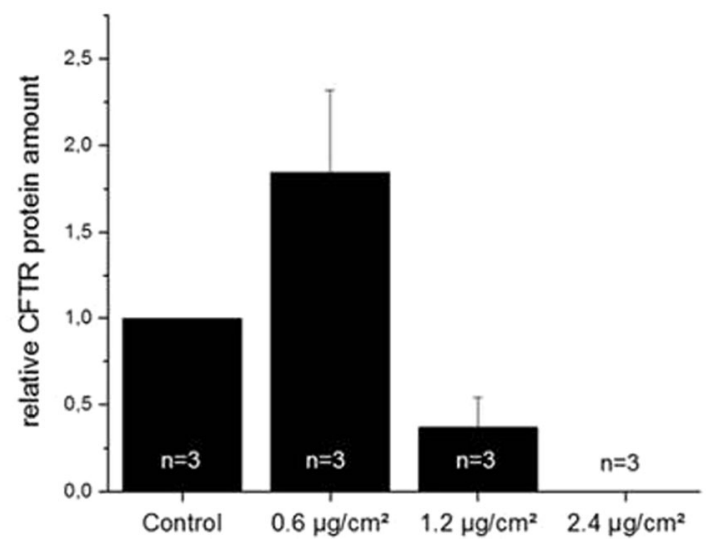

Fig. 5 Western blot analyses. Total membrane proteins $(40 \mu \mathrm{g})$ from HNE cells were isolated using $2 \%$ Triton X-100 and separated in a $7.5 \%$ SDS-PAGE. To identify CFTR, we used a monoclonal anti-CFTR antibody that detects a CFTR band in the range of $170 \mathrm{kDa}$. In addition, we detected tubulin in the range of $55 \mathrm{kDa}$ for normalization analyses. a HNE cells were transfected with different CFTR-mRNA doses $\left(2.4 \mu \mathrm{g} / \mathrm{cm}^{2}, 1.2 \mu \mathrm{g} / \mathrm{cm}^{2}, 0.6 \mu \mathrm{g} / \mathrm{cm}^{2}\right)$. b Statistical evaluation of the relative CFTR protein amount in transfected cells. Transfection with a CFTR-mRNA dose of $0.6 \mu \mathrm{g} / \mathrm{cm}^{2}$ expressed 1.8 -fold more CFTR protein. These results verify the efficiency of the $0.6 \mathrm{\mu g} / \mathrm{cm}^{2}$ dose as an optimal wtCFTR-mRNA concentration for CFTR expression

amiloride current via $\mathrm{ENaC}$ was found. On the other side, time dependence studies showed an increasing trend in the amiloride sensitive current (Fig. 8). The expression of $\mathrm{ENaC}$ is increased by the wtCFTR-mRNA transfection: $24 \mathrm{~h}(25.03 \% \pm 5.9 ; n=19), 48 \mathrm{~h}(29.51 \% \pm 8.1)$ and $72 \mathrm{~h}$ $(29.44 \% \pm 12)$. However, no statistical differences were found revealing no measurable effect of wtCFTR-mRNA transfection on $\mathrm{ENaC}$.

\section{Discussion}

The discovery of the disease-causing CFTR gene in 1989 [7] created new hopes for a curative treatment targeting the basic defect rather than treating CF disease manifestations [8]. Since this CFTR identification, there has been significant efforts to develop gene therapy strategies for the correction of the mutation on cellular level. The delivery of a therapeutic nucleic acid (DNA or RNA) is a promising concept for an inherited singlegene defect such as $\mathrm{CF}$, with the prospect of correcting many aspects of the complex pathology [25]. In addition, one single therapy might be suitable to treat subjects with a wide variety of mutations, meaning that a single treatment strategy would be relevant to all patients.
However, initially approaches, which involved direct administration to the airway of recombinant CFTR based on conventional viral DNA-delivery have not been successful for a number of reasons [26]. Subsequently, the development of mRNA-based therapeutic approaches presents several important differences in comparison with other nucleic acid-based therapies [27] like the direct translation in the cytoplasm, the missing integration into the genome and therefore the avoidance of the potential risk of insertional mutagenesis [28]. Therefore, as already described by our working group, we developed a new strategy using mRNA instead of DNA to correct CFTR function in the apical plasma membrane of human CF airway epithelia after wtCFTR-mRNA transfection in vitro [14]. Although other organs are affected in $\mathrm{CF}$ as well, the lung is the major site of pathology and thus, has been the target in the majority of gene therapy trials. Consequently, most investigators have focused towards minimizing CF lung disease [29]. In fact, the best target for the CF gene therapy in the airways are the ciliated epithelial cells [28]. Although it is known that CFTR constitutes a low-abundance mRNA in airway epithelia [30] a minor level of CFTR gene 


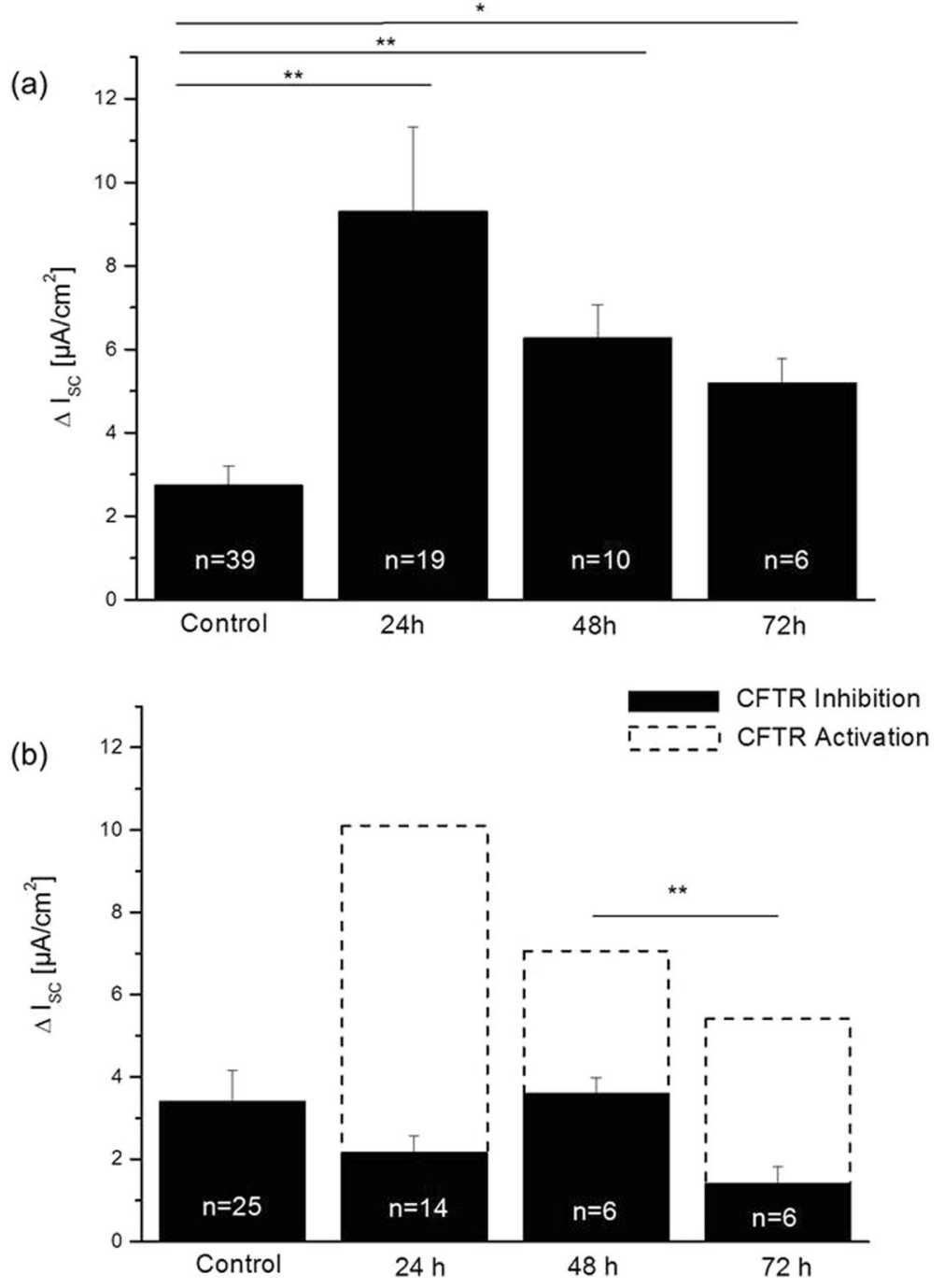

Fig. 6 Statistical evaluation of the wtCFTR-mRNA time dependency. Shown are the short-circuit values of CFTR activation by cAMP addition and the inhibition by CFTRinh172 application in HNE cells. a The CAMP activated chloride secretion is decreased according to time periods. Twenty-four hours after mRNA transfection with the optimal dose of $0.6 \mu \mathrm{g} / \mathrm{cm}^{2}$ the highest CFTR expression $\left(9.3 \pm 2.0 \mu \mathrm{A} / \mathrm{cm}^{2} ; n=19\right)$ was achieved. In comparison, longer time periods produced a decrease in the CFTR current. Nevertheless, we confirmed a positive CFTR activation over a period of $72 \mathrm{~h}\left(5.2 \pm 0.6 \mu \mathrm{A} / \mathrm{cm}^{2}\right.$; $n=6)$. $\mathbf{b}$ The inhibition by the CFTRinh172 is expanded in the wtCFTR-mRNA transfected cells. Since we could not observe a reduction by the inhibitor in the control cells, we found a $72.93 \%$ inhibition of the CAMP activated CFTR current in wtCFTR-mRNA transfected cells after $24 \mathrm{~h}(n=19)$. Therefore, the CFTR inhibition was found $48 \mathrm{~h}(37.18 \%)$ and even $72 \mathrm{~h}$ after transfection $(27.08 \%)\left({ }^{*} p<0.05 ;{ }^{* *} p<0.01\right)$

transfer to the airway epithelia is sufficient to correct the $\mathrm{Cl}^{-}$transport in vitro and in vivo [31]. Furthermore, only $10 \%$ of normal cells are sufficient to normalize the main dysregulated parameters such as $\mathrm{Cl}^{-}$or $\mathrm{Na}^{+}$ conductance and IL8 secretion [32].

\section{Dose and time dependence studies}

We used primary cultured human epithelial cells to perform our mRNA transfection experiments in a lipidbased transfection reagent to produce overexpression of CFTR protein. We have found that CFTR-mRNA can be effectively delivered in these primary cultured cells and that the expressed proteins are functional. The aim of this study was to find the optimal mRNA dose that is needed for an efficient chloride secretion mediated by the CFTR channel and to study the persistence of the wtCFTRmRNA transfection over a period of time. Therefore, we carried out Ussing chambers experiments and measured the transepithelial current $\left(\mathrm{I}_{\mathrm{sc}}\right)$ in transfected HNE cells and in non-transfected cells. We performed dose dependent studies, in which a stepwise dosage reduction was carried out, from 2.4 to $0.3 \mu \mathrm{g} / \mathrm{cm}^{2}$. In these measurements, we found that the most efficient CFTR activation was reached using a mRNA dose of $0.6 \mu \mathrm{g} / \mathrm{cm}^{2}$ compared to non-transfected cells. Furthermore, CFTR mediated current in time experiments studies confirmed that 


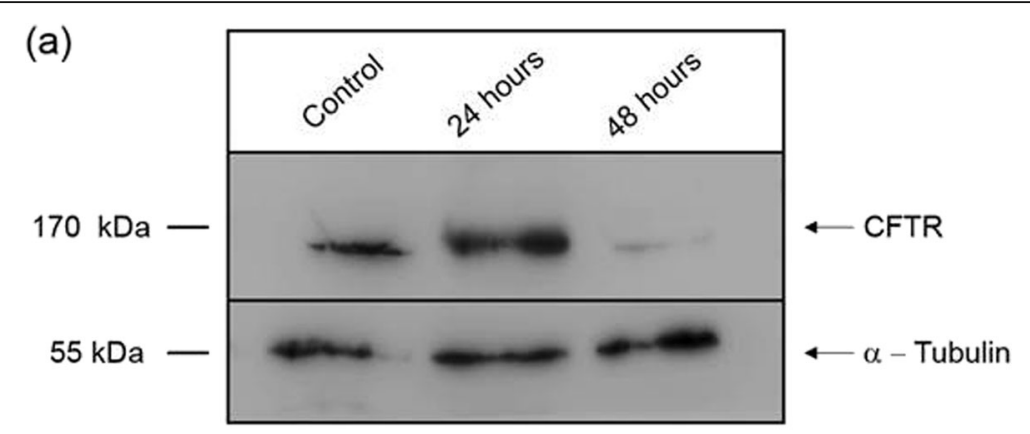

(b)

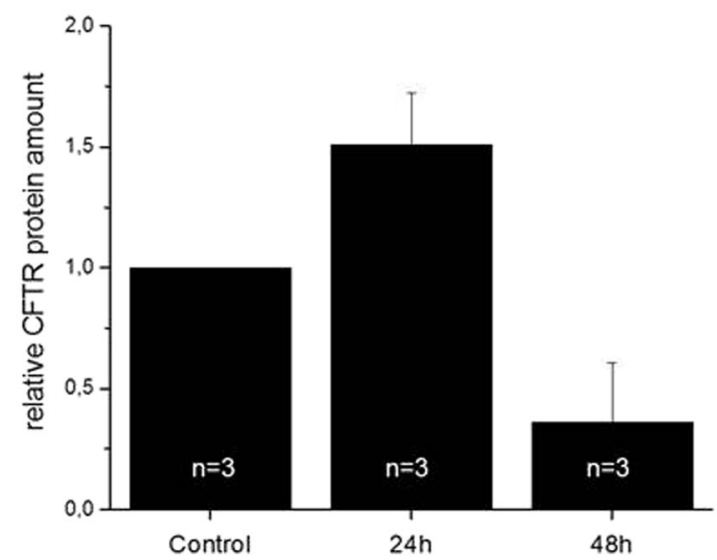

Fig. 7 Western blots analyses. Total membrane proteins $(40 \mu \mathrm{g})$ from HNE cells were isolated using $2 \%$ Triton X-100 and separated in a $7.5 \%$ SDS-PAGE. To identify CFTR, we used a monoclonal anti-CFTR antibody that detects a CFTR band in the range of $170 \mathrm{kDa}$. In addition, we detected tubulin in the range of $55 \mathrm{kDa}$. a HNE cells were transfected with wtCFTR-mRNA $\left(0.6 \mu \mathrm{g} / \mathrm{cm}^{2}\right)$ at different time periods $(24 \mathrm{~h}, 48 \mathrm{~h})$. $\mathbf{b}$ Statistical evaluation of the relative CFTR protein amount in transfected cells. Twenty-four hours after wtCFTR-mRNA transfection the amount of CFTR protein was increased (1.5-fold) compared to controls

$0.6 \mu \mathrm{g} / \mathrm{cm}^{2}$ wtCFTR-mRNA transfection could be persistent over a period of $72 \mathrm{~h}$.

Accordingly, we verified these findings using protein biochemistry analyses. First, we analysed the amount of CFTR using Western blot procedures. Thus, we showed that the HNE cells transfected with $0.6 \mu \mathrm{g} / \mathrm{cm}^{2}$ expressed nearly twice as much CFTR protein compared to control cells. These biochemical results correlate perfectly with the increase in the cAMP-induced current observed in the electrophysiological analyses. In time dependence studies, 24 after $0.6 \mu \mathrm{g} / \mathrm{cm}^{2}$ wtCFTR- mRNA transfection 1.5 - fold more CFTR protein compared to non-transfected cells was shown. Here, the obtained results indicated that the functional CFTR protein can be maintained in the plasma membrane over a few days in HNE cells. Nonetheless, after $48 \mathrm{~h}$ less protein are detectable due to the potential degradation of the CFTR. CFTR expression using unmodified mRNA decreased within 3 days, requiring repeated application in high frequencies [33, 34]. Moreover, possible difficulties in long-term effect may also include mRNA stability and therefore the duration of the mRNA effect in the target cells, which could make frequent dosing necessary.

\section{Does the boosted CFTR expression affect ENaC?}

In CF disease, salt and fluid absorption is prompted by the loss of CFTR and the inappropriate regulation of $\mathrm{ENaC}$ [3]. The consequence is an increase in water and sodium reabsorption from the airways, compromising the formation of a sufficient periciliary liquid layer and mucus clearance [35]. In CF airways, $\mathrm{ENaC}$ is stimulated by the increase in cAMP concentrations when functional CFTR is lacking, suggesting that CFTR acts in decreasing ENaC activity [35-37]. To better understand CFTR/ $\mathrm{ENaC}$ interactions as well as to determine the role of $\mathrm{ENaC}$ in wtCFTR-mRNA transfection experiments in primary cultured human epithelial cells, electrophysiological measurements in Ussing chambers were carried out to study $\mathrm{ENaC}$ activity in the presence of boosted CFTR expression. As expected, the control cells had the highest amiloride-sensitive current. It is well known that primary HNE cells have an amiloride-sensitive current $[38,39]$. In comparison, in cells transfected with different doses of wtCFTR-mRNA the transepithelial $\mathrm{ENaC}$ current decreased stepwise, possibly showing a trend in the down-regulation of ENaC by CFTR (Fig. 8a). 

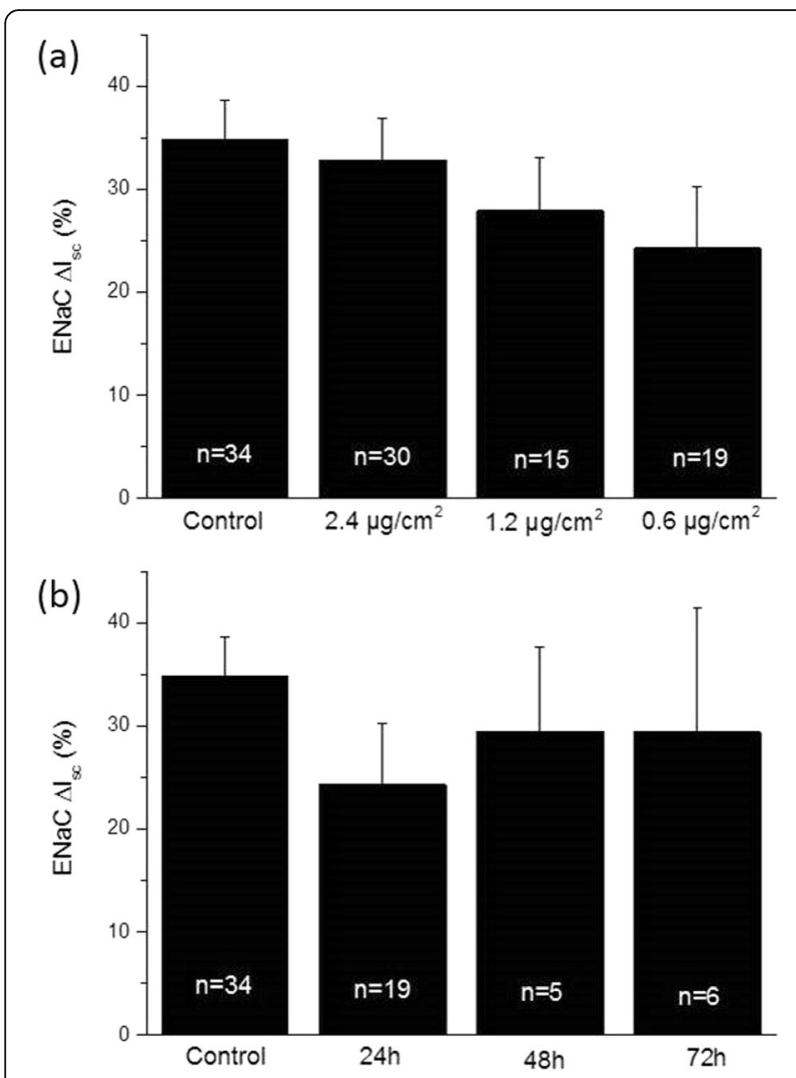

Fig. 8 Statistical evaluation of the amiloride-sensitive current in dependence of the wtCFTR-mRNA. a Shown is the decreasing trend in $\mathrm{ENaC}$ expression in primary HNE cells $24 \mathrm{~h}$ after wtCFTR-mRNA transfection using different concentrations $2.4 \mu \mathrm{g} / \mathrm{cm}^{2}(32.85 \% \pm$ $3.8 ; n=34), 1.2 \mu \mathrm{g} / \mathrm{cm}^{2}(27.92 \% \pm 5.1 ; n=18), 0.6 \mu \mathrm{g} / \mathrm{cm}^{2}$ (25.03\% $\% 5.9$; $n=19$ ). There is no statistical significance. $\mathbf{b}$ Shown is the increasing trend in $\mathrm{ENaC}$ expression in primary HNE cells after $0.6 \mu \mathrm{g} / \mathrm{cm}^{2}$ wtCFTRmRNA transfection using different time periods: $24 \mathrm{~h}(25.03 \% \pm$ $5.9 ; n=19), 48 \mathrm{~h}(29.51 \% \pm 8.1)$ and $72 \mathrm{~h}(29.44 \% \pm 12)$. No statistical difference was found

However, no significant statistical difference was found, and therefore no effects of the transfection on $\mathrm{ENaC}$ function or expression were confirmed. On the other side, in time dependence studies an increasing trend in the amiloride-sensitive current was found (Fig. 8b), although no statistical difference was found, too. In a certain way, these results indicate a down-regulation of $\mathrm{ENaC}$ by CFTR. Firstly, the inhibition of $\mathrm{ENaC}$ was shown by a decreasing tendency in the amiloridesensitive current after overexpression of CFTR with different wtCFTR-mRNA doses. Secondly, the restoration of $\mathrm{ENaC}$ was measured by an increasing trend of $\mathrm{ENaC}$ current after wtCFTR-mRNA transfection in time dependence experiments. Further studies, not only functional electrophysiological measurements but also biochemical and immunological studies are necessary to confirm these findings. In summary, more than 20 years after the initial discovery that ENaC's sensitivity to
cAMP is CFTR dependent, the mechanism of the CFTR/ENaC interaction, and in particular the $\mathrm{ENaC}$ regulation by CFTR, still remains unclear. Undoubtedly, $\mathrm{ENaC}$ represents an attractive alternative target to improve airway surface hydration and mucus clearance in patients with CF independent of their CFTR genotype.

\section{Different delivery methods}

In CF pulmonary disease the opportunity to selectively target a drug to the lungs remains a fascinating option [40]. In fact, local drug delivery may allow maximum pharmacological targeting, and thus therapeutic efficacy. As a consequence, researchers continue applied efforts to develop new inhalation devices and advanced drug delivery [41]. CFTR-mRNA aerosol administration to airways of CF patients could be delivered as it was previously showed [42]. Furthermore, another study successfully demonstrates the gene delivery with magnetized aerosol comprising iron oxide nanoparticles in lungs of mice [43]. Therefore, administration of drugs via the inhalation route is of great interest in CF treatment [44]. The main advantages of aerosol technologies are the limited systemic toxicity, direct drug action on target site and the suitability for home therapy [45]. An important issue in gene delivery is the biocompability and biosafety of the nanocarrier used in the transfection procedure [46]. Lipid based formulations like cationic lipids o cationic polymers have become a successful method to transfect cells and to reach adequate transfection efficiency in vitro [15, 47]. Here, this study demonstrates promising results using this lipid-based delivery by Lipofectamine 2000 transfection reagent in primary cultured cells. On the other side, since Lipofectamine presents a high cytotoxicity for the cell viability despite its robust and high transfection efficiency [48], it is not an appropriate carrier to assess potentially clinical in vivo therapies in treatment of CF. Therefore, we are looking for an alternative and stable formulation like biopolymers, e.g. chitosan, that could be effective to target intratracheal routes. Efficient transfection in a CF cell line may show the future use of this nanocarrier in the gene therapy approaches. Nevertheless, the search for an optimal transfection agent is still open in the hope of finding a solution to address the barriers associated by the lung.

\section{Future aspects: clinical application/dosage form}

One of the major milestones for a potential clinical application of the mRNA based gene therapy is to circumvent unwanted immune responses, instability and delivery barriers. Chemical modifications of the mRNA, like the inclusion of pseudouridine in the mRNA prevented activation pattern recognition receptors [49] and 2'-5'-oligoadenylate synthetase [50]. Furthermore, these modifications can stabilize the mRNA against cleavage and ultimately improve expression 
rates [47]. These variations present new alternative therapies to avoid side effects and therefore the clinical application is in sight [51]. In addition, efficient pulmonary drug delivery has been mostly achieved through specific devices and particle engineering technologies [52]. The face of the future in CF lung therapy is the development of easy to use dry powder for inhalation [53]. In this context, biocompatible nanoparticles, such as chitosan nanoparticles, are very suitable candidates because they permit an efficient protection of the gene material and its delivery to airway epithelial cells. In addition, despite chitosan biodegradability, future lung deposition studies should achieve the issue of chitosanwtCFTR-mRNA complexes fate after they have landed. Furthermore, other challenges concerning targeting the lung should be considered because it is an immunologically sensitive organ and the airway cells turn over [54]. For instance, higher doses are generally required for the effective administration to the lung [28] and sustainable expression of the therapeutic gene is difficult to achieve. Therefore, the potential dosage of chitosan-wtCFTR-mRNA complexes could demand a repeated administration. Multi dose clinical trials could achieve improvement in lung function, long-term expression and subsequently, future clinical benefits for $\mathrm{CF}$ patients.

\section{Conclusions}

We have clearly demonstrated that wtCFTR-mRNA can be effectively delivered in primary cultured human nasal epithelial cells, and that the expressed proteins are functional. Moreover, we have shown that CFTR-mRNA can be reduced to minimal dose and is persistent for a time period longer than $24 \mathrm{~h}$ after transfection. Furthermore, we could not find any effect on $\mathrm{ENaC}$ activity after the reconstitution of CFTR by transfection. Our study establishes the efficient mRNA transfection using primary cultured cells, thus creating the more physiological relevant conditions for further approaches in the potentially development of therapeutic strategies for CF disease treatment.

\footnotetext{
Abbreviations

$\%$ : Percent; *: Significance level of $p p \leq 0.05$; **: Significance level of $p \leq 0.01$; ${ }^{\circ} \mathrm{C}$ : Degree celsius; A: Ampere; ABC: ATP-binding cassette-Transporter; ATP: Adenosin triphosphate; BCA: Bicinchoninin acid; bp: Base pair; C: Capacitance; CAMP: Cyclic adenosine monophosphate; CF: Cystic Fibrosis; CFBE410-: Cystic Fibrosis Bronchial Epithelial 410- Cells; CFTR: Cystic fibrosis transmembrane conductance regulator; $\mathrm{Cl}$-: Chloride ion; $\mathrm{Cm}$ : Centimeter; $\mathrm{Cm}^{2}$ : Square centimeter; $\mathrm{CO}_{2}$ : Carbon dioxide; Da: Dalton; DNA: Deoxyribonucleic acid; ECL: Enhanced chemiluminescence; EDTA: Ethylenediaminetetraacetic acid; ENaC: Epithelial sodium channel; g: Gram; GFP: Green fluorescence protein; h: Human; h: Hour; $\mathrm{H}_{2} \mathrm{O}$ : Water; HEPES: 4-(2-hydroxyethyl)-1-piperazineethanesulfonic acid; HNE cells: Human nasal epithelial cells; hrp: Horseradish peroxidase; HUVEC: Human umbilical vein endothelial cells; IBMX: 3-isobutyl-1-methylxanthine; Ig: Immunoglobulin; IL: Interleukin; Im: Membrane current; Isc: Short-circuit current; $\mathrm{VT}$ : In vitro transcription; kb: Kilobase; kDa: Kilodalton; I: Liter; M: Molar; MEM: Minimum essential medium; min: Minutes; mM: Millimolar; mRNA: Messenger ribonucleic acid; $\mathrm{Na}^{+}$: Sodium ion; $P$. aeruginosa: Pseudomonas aeruginosa; PAGE: Polyacrylamide gel electrophoresis; PCR: Polymerase chain reaction; PVDF: Polyvinylidene fluoride; RGB: Red-green-blue; RNA: Ribonucleic acid; $R_{t}$ : Transepithelial electrical resistance; RT: Room temperature; RT: Reverse
}

transcriptase; SDS: Sodium dodecyl sulfate; SEM: Standard error of the mean; siRNA: Small-interfering RNA; TBS: Tris buffered saline; TBS-T: Tris buffered salineTween; wt: Wildtyp; a: Alpha; $\mu$ : Micro

\section{Acknowledgements}

We acknowledge financial support from "Deutsche Förderungsgesellschaft zur Mukoviszidoseforschung e.V.". We thank Cristin Brand for her technical support in the cell characterization assay and Lisa Träger for helpful discussions of the manuscript.

\section{Funding}

PhD fellowship from "Deutsche Förderungsgesellschaft zur Mukoviszidoseforschung e.V." to EFF.

\section{Availability of data and materials}

Please contact author for data requests.

\section{Authors' contributions}

EFF designed and performed experiments, analysed data and wrote the paper. NBR and KT supervised the project, participated in the design of the study and helped to draft the manuscript. WMW conceived of the study, and participated in its design and coordination and helped to draft the manuscript. All authors read and approved the final manuscript.

\section{Competing interests}

The authors declare that they have no competing interests.

\section{Consent for publication}

Not applicable.

\section{Ethics approval and consent to participate}

We obtained the nasal specimens from non-CF patients undergoing nasal surgery. Typically the samples were nasal polyps or nasal turbinates of patients suffering from chronic sinusitis. The study was approved by the committees for human studies of the University of Muenster (Ethik Kommission Muenster). This study was conducted according to the principles expressed in the Declaration of Helsinki and all patients provided their informed consent.

Received: 30 April 2016 Accepted: 24 September 2016

Published online: 04 October 2016

\section{References}

1. Lubamba B, Dhooghe B, Noel S, Leal T. Cystic fibrosis: insight into CFTR pathophysiology and pharmacotherapy. Clin Biochem. 2012;15:1132-44.

2. Briel M, Greger R, Kunzelmann K. Cl- transport by cystic fibrosis transmembrane conductance regulator (CFTR) contributes to the inhibition of epithelial $\mathrm{Na}+$ channels (ENaCs) in Xenopus oocytes co-expressing CFTR and ENaC. J Physiol. 1998:508(Pt 3):825-36.

3. Boucher RC, Cotton CU, Gatzy JT, Knowles MR, Yankaskas JR. Evidence for reduced $\mathrm{Cl}$ - and increased $\mathrm{Na}+$ permeability in cystic fibrosis human primary cell cultures. J Physiol. 1988;405:77-103.

4. Bangel-Ruland N, Tomczak K, Weber W-M. Targeting ENaC as a Molecular Suspect in Cystic Fibrosis. Curr Drug Targets. 2015;16(9):951-7.

5. Callaghan M, McClean S. Bacterial host interactions in cystic fibrosis. Curr Opin Microbiol. 2012;15(1):71-7.

6. Cutting GR. Cystic fibrosis genetics: from molecular understanding to clinical application. Nat Rev Genet. 2015;16(1):45-56.

7. Riordan JR, Rommens JM, Kerem B, Alon N, Rozmahel R, Grzelczak Z, et al. Identification of the cystic fibrosis gene: cloning and characterization of complementary DNA. Science. 1989;245(4922):1066-73.

8. Clancy JP, Jain M. Personalized medicine in cystic fibrosis: dawning of a new era. Am J Respir Crit Care Med. 2012;186(7):593-7.

9. Mackenzie T, Gifford AH, Sabadosa KA, Quinton HB, Knapp EA, Goss CH, et al. Longevity of patients with cystic fibrosis in 2000 to 2010 and beyond: survival analysis of the Cystic Fibrosis Foundation patient registry. Ann Intern Med. 2014;161(4):233-41.

10. Armstrong DK, Cunningham S, Davies JC, Alton EW. Gene therapy in cystic fibrosis. Arch Dis Child. 2014;99(5):465-8.

11. Koido S, Kashiwaba M, Chen D, Gendler S, Kufe D, Gong J. Induction of antitumor immunity by vaccination of dendritic cells transfected with MUC1 RNA. J Immunol. 2000;165(10):5713-9. 
12. Schirmacher V, Forg P, Dalemans W, Chlichlia K, Zeng Y, Fournier P, et al. Intra-pinna anti-tumor vaccination with self-replicating infectious RNA or with DNA encoding a model tumor antigen and a cytokine. Gene Ther. 2000;7(13):1137-47.

13. Lai W-F, Lin MC-M. Nucleic acid delivery with chitosan and its derivatives. J Control Release. 2009:134(3):158-68.

14. Bangel-Ruland N, Tomczak K, Fernández Fernández E, Leier G, Leciejewski B, Rudolph C, et al. Cystic fibrosis transmembrane conductance regulatormRNA delivery: a novel alternative for cystic fibrosis gene therapy. J Gene Med. 2013;15(11-12):414-26.

15. Cho H-J, Choi M-K, Lin H, Kim JS, Chung S-J, Shim C-K, et al. Expression and functional activity of P-glycoprotein in passaged primary human nasal epithelial cell monolayers cultured by the air-liquid interface method for nasal drug transport study. J Pharm Pharmacol. 2011;63(3):385-91.

16. Kim D-D. In vitro cellular models for nasal drug absorption studies. In: Drug Absorpt Stud. Ehrhardt C, Kim K, editors. Boston: Springer US; 2008. p. 216-234.

17. McDougall CM, Blaylock MG, Douglas JG, Brooker RJ, Helms PJ, Walsh GM. Nasal epithelial cells as surrogates for bronchial epithelial cells in airway inflammation studies. Am J Respir Cell Mol Biol. 2008;39(5):560-8.

18. Kormann MS, Hasenpusch G, Aneja MK, et al. Expression of therapeutic proteins after delivery of chemically modified mRNA in mice. Nat Biotechnol. 2011;29:154-7.

19. Blank U, Clauss W, Weber W-M. Effects of benzamil in human cystic fibrosis airway epithelium. Cell Physiol Biochem. 1995;5:385-90.

20. Päll T, Pink A, Kasak L, Turkina M, Anderson W, Valkna A, et al. Soluble CD44 interacts with intermediate filament protein vimentin on endothelial cell surface. PLoS One. 2011;6(12):e29305.

21. Rosario FJ, Sadovsky Y, Jansson T. Gene targeting in primary human trophoblasts. Placenta. 2012;33(10):754-62.

22. Jain S, Kumar S, Agrawal AK, Thanki K, Banerjee UC. Enhanced transfection efficiency and reduced cytotoxicity of novel lipid-polymer hybrid nanoplexes. Mol Pharm. 2013;10(6):2416-25.

23. Brezillon S, Dupuit F, Hinnrasky J, Marchand V, Kalin N, Tummler B, et al. Decreased expression of the CFTR protein in remodeled human nasal epithelium from non-cystic fibrosis patients. Lab Invest. 1995;72(2):191-200.

24. Dupuit F, Kalin N, Brezillon S, Hinnrasky J, Tummler B, Puchelle E. CFTR and differentiation markers expression in non-CF and delta $F 508$ homozygous CF nasal epithelium. J Clin Invest. 1995;96(3):1601-11.

25. Gill DR, Hyde SC. Delivery of genes into the CF airway. Thorax. 2014;69(10):962-4.

26. Griesenbach U, Alton EW. Cystic fibrosis gene therapy: successes, failures and hopes for the future. Expert Rev Respir Med. 2009;3(4):363-71.

27. Sahin U, Karikó K, Türeci Ö. mRNA-based therapeutics-developing a new class of drugs. Nat Rev Drug Discov. 2014;13(10):759-80.

28. Kay MA. State-of-the-art gene-based therapies: the road ahead. Nat Rev Genet. 2011;12(5):316-28

29. Davis PB, Drumm ML, Konstan MW. Cystic fibrosis. Am J Respir Crit Care Med 1996; 154 (5):1229-56.

30. Ramachandran S, Karp PH, Osterhaus SR, Jiang P, Wohlford-Lenane C, Lennox KA, et al. Post-Transcriptional Regulation of Cystic Fibrosis Transmembrane Conductance Regulator Expression and Function by MicroRNAs. Am J Respir Cell Mol Biol. 2013;49(4):544-51.

31. Ramalho AS, Beck S, Meyer M, Penque D, Cutting GR, Amaral MD. Five percent of normal cystic fibrosis transmembrane conductance regulator mRNA ameliorates the severity of pulmonary disease in cystic fibrosis. Am J Respir Cell Mol Biol. 2002;27:619-27.

32. Dannhoffer L, Blouquit-Laye $S$, Regnier A, Chinet T. Functional properties of mixed cystic fibrosis and normal bronchial epithelial cell cultures. Am Respir Cell Mol Biol. 2009;40(6):717-23.

33. Kuhn AN, Beissert T, Simon P, Vallazza B, Buck J, Davies BP, et al. mRNA as a versatile tool for exogenous protein expression. Curr Gene Ther. 2012;12(5):347-61.

34. Frizzell RA, Hanrahan JW. Physiology of epithelial chloride and fluid secretion. Cold Spring Harb Perspect Med. 2012;2(6):a009563.

35. Riordan JR. Cystic fibrosis as a disease of misprocessing the cystic fibrosis transmembrane conductance regulator glycoprotein. Am J Hum Genet. 1999;64(6):1499-504.

36. Berdiev BK, Cormet-Boyaka E, Tousson A, Qadri YJ, Oosterveld-Hut HM, Hong JS, et al. Molecular proximity of cystic fibrosis transmembrane conductance regulator and epithelial sodium channel assessed by fluorescence resonance energy transfer. J Biol Chem. 2007;282(50):36481-8.
37. Gaillard E a, Kota P, Gentzsch M, Dokholyan NV, Stutts MJ, Tarran R. Regulation of the epithelial $\mathrm{Na}+$ channel and airway surface liquid volume by serine proteases. Pflugers Arc. 2010;460(1):1-17.

38. Blank U, Rückes $C$, Clauss W, Hofmann T, Lindemann H, Münker G, et al. Cystic fibrosis and non-cystic-fibrosis human nasal epithelium show analogous $\mathrm{Na}+$ absorption and reversible block by phenamil. Pflugers Arch. 1997;434(1):19-24.

39. Rückes C, Blank U, Möller K, Rieboldt J, Lindemann H, Münker G, et al. Amiloride-sensitive $\mathrm{Na}+$ channels in human nasal epithelium are different from classical epithelial $\mathrm{Na}+$ channels. Biochem Biophys Res Commun. 1997;237(3):488-91.

40. Grasemann H, Ratjen F. Emerging therapies for cystic fibrosis lung disease Expert Opin Emerg Drugs. 2010;15(4):653-9.

41. Daniels T, Mills N, Whitaker P. Nebuliser systems for drug delivery in cystic fibrosis. Paediatr Respir Rev. 2013;14(2):98-9.

42. Rudolph C, Ortiz A, Schillinger U, Jauernig J, Plank C, Rosenecker J. Methodological optimization of polyethylenimine (PEI)-based gene delivery to the lungs of mice via aerosol application. J Gene Med. 2005;7(1):59-66.

43. Hasenpusch G, Geiger J, Wagner K, Mykhaylyk O, Wiekhorst F, Trahms L, et al. Magnetized aerosols comprising superparamagnetic iron oxide nanoparticles improve targeted drug and gene delivery to the lung. Pharm Res. 2012;29(5):1308-18.

44. Ibrahim BM, Tsifansky MD, Yang Y, Yeo Y. Challenges and advances in the development of inhalable drug formulations for cystic fibrosis lung disease. Expert Opin Drug Deliv. 2011;8(4):451-66.

45. Rubin BK, Williams RW. Emerging aerosol drug delivery strategies: from bench to clinic. Adv Drug Deliv Rev. 2014;75:141-8.

46. Xia DL, Wang YF, Bao N, He H, Li XD, Chen YP, et al. Influence of reducing agents on biosafety and biocompatibility of gold nanoparticles. Appl Biochem Biotechnol. 2014;174(7):2458-70.

47. Kariko K, Muramatsu H, Keller JM, Weissman D. Increased erythropoiesis in mice injected with submicrogram quantities of pseudouridine-containing mRNA encoding erythropoietin. Mol Ther. 2012;20(5):948-53.

48. Zhong YQ, Wei J, Fu YR, Shao J, Liang YW, Lin YH, et al. Toxicity of cationic liposome Lipofectamine 2000 in human pancreatic cancer Capan-2 cells. Nan Fang Yi Ke Da Xue Xue Bao. 2008;28(11):1981-4.

49. Kariko K, Buckstein M, Ni H, Weissman D. Suppression of RNA recognition by toll-like receptors: the impact of nucleoside modification and the evolutionary origin of RNA. Immunity. 2005;23(2):165-75.

50. Anderson BR, Muramatsu H, Jha BK, Silverman RH, Weissman D, Kariko K. Nucleoside modifications in RNA limit activation of 2'-5'-oligoadenylate synthetase and increase resistance to cleavage by RNase L. Nucleic Acids Res. 2011;39(21):9329-38.

51. Yin H, Kanasty RL, Eltoukhy AA, Vegas AJ, Dorkin JR, Anderson DG. Non-viral vectors for gene-based therapy. Nat Rev Genet. 2014;15(8):541-55.

52. Patil JS, Sarasija S. Pulmonary drug delivery strategies: A concise, systematic review. Lung India. 2012;29(1):44-9.

53. Muralidharan P, Hayes Jr D, Mansour HM. Dry powder inhalers in COPD, lung inflammation and pulmonary infections. Expert Opin Drug Deliv. 2015; 12(6):947-62.

54. Rawlins EL, Hogan BLM. Ciliated epithelial cell lifespan in the mouse trachea and lung. American Journal of Physiology. Am J Physiol Lung Cell Mol Physiol. 2008;295(1):L231-4.

\section{Submit your next manuscript to BioMed Central and we will help you at every step:}

- We accept pre-submission inquiries

- Our selector tool helps you to find the most relevant journal

- We provide round the clock customer support

- Convenient online submission

- Thorough peer review

- Inclusion in PubMed and all major indexing services

- Maximum visibility for your research

Submit your manuscript at www.biomedcentral.com/submit 